\title{
A series of eIF4E alleles at the $B c-3$ locus are associated with recessive resistance to Clover yellow vein virus in common bean
}

\author{
John P. Hart $\cdot$ Phillip D. Griffiths
}

Received: 28 December 2012 / Accepted: 27 July 2013 / Published online: 11 August 2013

(C) Springer-Verlag Berlin Heidelberg 2013

\begin{abstract}
Clover yellow vein virus (ClYVV) is capable of causing severe damage to common bean (Phaseolus vulgaris L.) production worldwide. The snap bean market class is particularly vulnerable because infection may lead to distortion and necrosis of the fresh green pods and rejection of the harvest. Three putatively independent recessive genes (cyv, desc, bc-3) have been reported to condition resistance to ClYVV; however, their allelic relationships have not been resolved. We identified, evaluated, and characterized the phenotypic and molecular genetic variation present in 21 informative common bean genotypes for resistance to CIYVV. Allelism testing phenotypes from multiple populations provided clear evidence that the three genes were a series of recessive alleles at the $B c-3$ locus that condition unique potyvirus strain- and species-specific resistance spectra. Candidate gene analysis revealed complete association between the recessive resistance alleles and unique patterns of predicted amino acid substitutions in $P$. vulgaris eukaryotic translation initiation factor $4 \mathrm{E}$ (PveIF4E). This led to the discovery and characterization of two novel PveIF4E alleles associated with resistance to CIYVV, PveIF4E ${ }^{3}$, and PveIF4E ${ }^{4}$. We developed KASPar
\end{abstract}

Communicated by B. Hulke.

The GenBank accession numbers for the sequences reported in this paper are KC417354-KC417372.

Electronic supplementary material The online version of this article (doi:10.1007/s00122-013-2176-8) contains supplementary material, which is available to authorized users.

J. P. Hart · P. D. Griffiths $(\square)$

Department of Plant Breeding and Genetics, Cornell University,

New York State Agricultural Experiment Station, Geneva,

NY 14456, USA

e-mail: pdg8@cornell.edu allele-specific SNP genotyping assays and demonstrated their ability to accurately detect and differentiate all of the PveIF4E haplotypes present in the germplasm, allelism testing, and in three separate segregating populations. The results contribute to an enhanced understanding and accessibility of the important potyvirus resistance conditioned by recessive alleles at $B c-3$. The KASPar assays should be useful to further enable germplasm exploration, allelic discrimination, and marker-assisted introgression of $b c-3$ alleles in common bean.

\section{Introduction}

Clover yellow vein virus (ClYVV) (family Potyviridae, genus Potyvirus) infection is capable of causing significant damage to leguminous crop and forage plants around the world (CABI/EPPO 2000). The impact of the disease can be particularly severe in certain interactions with the common bean (Phaseolus vulgaris L.) because symptom expression can include severe stunting, prominent mosaic, premature defoliation, systemic necrosis, and in some cases plant death (Provvidenti and Morales 2005). The impact can be even more acute in the snap bean market class where CIYVV has the potential to devastate marketable yield by causing twisting, distortion, and necrosis of the fresh green pods (Larsen and Myers 2006; Larsen et al. 2008; Provvidenti and Morales 2005). The threat of direct economic damage is compounded when pod-distorting strains of the virus appear in processing snap bean production regions as the presence of distorted or necrotic pods above a threshold may result in the rejection of the entire harvest by the processor.

CIYVV epidemics appear to occur sporadically in numerous regions where common beans are grown (CABI/EPPO 2000; Crnov and Gilbertson 2001; Dizadji 
and Shahraeen 2011; Larsen and Myers 2006; Ortiz et al. 2009; Provvidenti and Schroeder 1973; Sasaya et al. 1997; Tu 1980, 1988), but the increased frequency of an aphidtransmitted virus disease complex of snap beans in the Great Lakes Region of the United States over the past decade has been cause for concern (Larsen et al. 2002, 2008; Shah et al. 2006). Processing snap bean is a major vegetable crop in this region where the farm-gate value alone exceeds \$100 million (USDA-NASS 2011). A number of aphid species are present in the region that are potential vectors of ClYVV (Nault et al. 2004), but the increased incidence of ClYVV (and other viruses) in snap bean production has been associated with the accidental introduction of the soybean aphid (Aphis glycines Matsumura) to the United States in 2000 or earlier (Hill et al. 2001; Ragsdale et al. 2004). Aphid vectors transmit ClYVV in a nonpersistent manner where the virus may be acquired and transmitted within seconds of stylet penetration (Nault 1997; Nault et al. 2004). For this reason and others, nonpersistent aphid-transmitted viruses can be exceedingly difficult to control. Host plant resistance, if available, is the most effective, efficient, and ecologically sensitive means to reduce the potential for crop damage.

Genetic variation for resistance to ClYVV in common bean has been identified. The $b y-3$ gene was first identified in GN 1140 where it provided homozygous recessive resistance to a number of isolates of the severe (pod-distorting) strain of Bean yellow mosaic virus (BYMV-S) (Provvidenti and Schroeder 1973). The by-3 gene symbol was subsequently revised to $c y v$ by Provvidenti (1987) to reflect taxonomic revision of BYMV-S to ClYVV (as proposed by Bos et al. 1977, substantiated by Uyeda et al. 1991 and Tracy et al. 1992). A single gene in Kentwood that was donated by Clipper conditioned homozygous recessive resistance to a necrotic strain of ClYVV previously typed as BYMV-N from Ontario, Canada (Tu 1980, 1983). Genetic analysis of the resistance present in GN UI 31 to an isolate of BYMV$\mathrm{S}$ from Oregon revealed that two recessive genes were required for resistance (Tatchell et al. 1985). Subsequent research demonstrated that the recessive $c y v$ gene present in GN 1140 was allelic with the ClYVV resistance present in the cultivars Kentwood, Harokent, Imuna, and Amanda (Park and Tu 1991).

The mechanism of resistance present in Jolanda to the ClYVV no. 30 strain from Japan was characterized by employing a ClYVV vector that expressed green fluorescent protein (pClYVV/C3-S65T) (Sato et al. 2003). The results demonstrated that the resistance phenotype operated on the single-cell level by completely inhibiting CIYVV replication in healthy cells (Sato et al. 2003). A spontaneous resistance-breaking mutant of the virus (ClYVV$\mathrm{Br}$ ) was then utilized to develop chimeric clones and to map the avirulence determinant of the virus. The results suggested that the viral genome-linked protein (VPg) was the avirulence determinant (Sato et al. 2003) similar to that observed in other plant-potyvirus pathosystems (Hjulsager et al. 2002; Keller et al. 1998; Nicolas et al. 1997). Genetic analysis revealed that the resistance was conditioned by a single recessive gene which was separate from the potyvirus resistance conferred by the Bean common mosaic virus (BCMV) resistance genes $I, b c-1$, and $b c-u$ which were also present in Jolanda (Drijfhout 1978; Sato et al. 2003). The resistance gene was designated desc (determinant of susceptibility to CIYVV) to reflect the hypothesis that it was based on the absence of a factor necessary for viral infection and replication, and possibly analogous to the phenomenon of recessive resistance conditioned by mutations in eukaryotic translation initiation factor 4E (eIF4E) and its isoform (eIF(iso)4E) as elucidated in Capsicum spp. (Ruffel et al. 2002) and Arabidopsis thaliana (Lellis et al. 2002), respectively. Allelism testing with additional CIYVV no. 30 resistant bean cultivars Evolutie and Imuna revealed that they possessed the same desc resistance (Sato et al. 2003). The allelic relationship between desc and the previously identified cyv gene reported in Imuna (Park and Tu 1991) was not established. In addition, it appears the hypothesis that mutations in eIF4E or eIF(iso)4E present in Jolanda conferred resistance to CIYVV no. 30 was never tested.

A novel strain of ClYVV from Wisconsin (ClYVV-WI) associated with an emerging U.S. Great Lakes virus disease complex was recently discovered and characterized (Larsen et al. 2008). ClYVV-WI infection caused severe symptoms in a collection of 63 commercial snap bean cultivars and other common bean genotypes, including the previously reported resistant cultivars Imuna and Jolanda (Larsen et al. 2008). Complete resistance to ClYVV-WI, as well as the New York (ClYVV-NY) and Oregon (ClYVVOR) strains, was identified in all common bean genotypes that possessed the recessive $b c-3$ gene (USLK-1, USLK-2, USDK-4, USDK-5, USWK-6, USCR-7, USCR-8, USCR9, and Raven) with the exception of IVT 7214 (Larsen et al. 2008). The potential involvement of $b c-3$ is particularly interesting given that its combination with the $b c-u$, and/ or I gene(s) (Ali 1950; Collmer et al. 2000) confers resistance to all known strains of the related potyviruses Bean common mosaic virus (BCMV) and Bean common mosaic necrosis virus (BCMNV) worldwide (Drijfhout 1978; Kelly et al. 1995; McKern et al. 1992), except the recombinant NL 3 K strain of BCMV/BCMNV (Larsen et al. 2005).

The $b c-3$ gene is one of six recessive alleles $(b c-u, b c-1$, $b c-1^{2}, b c-2, b c-2^{2}$, and $\left.b c-3\right)$ at four independent loci, that along with the dominant allele of the $I$ gene act in allelespecific combinations to condition resistance, and to define seven pathogenicity groups of BCMV and BCMNV (for reviews, see Drijfhout 1978; Drijfhout et al. 1978; Kelly et al. 1995; Morales 2005; Mukeshimana et al. 2005). Full 
expression of the resistance conditioned by the five strainspecific alleles $\left(b c-1, b c-1^{2}, b c-2, b c-2^{2}\right.$, and $\left.b c-3\right)$ requires the homozygous recessive state of the strain nonspecific $b c-u$ gene when the dominant allele of the $I$ gene is absent (Drijfhout 1978). When the $I$ gene is present in $B c-u$ genotypes, all resistance alleles are fully expressed except for those at the $b c-2$ locus (Kelly et al. 1995). The $i, B c-u, b c-3$ combination is known to condition resistance to all known strains of BCMNV, but not to all strains of BCMV (US1, US3, US7), although another uncharacterized gene that interacts with $b c-3$ may be responsible for this resistance spectrum (Miklas et al. 1998). The allele combinations $I$, $b c-3$ as well as $b c-u, b c-3$, condition resistance to all known strains of BCMV, BCMNV (except NL $3 \mathrm{~K}$ ), and all known strains of ClYVV (Larsen et al. 2008). Due to the critical importance of the resistance spectrum conditioned by $b c$ 3 , and its recessive inheritance, common bean breeders and geneticists have invested in the development and employment of molecular markers to map $b c-3$ to common bean chromosome 6 , and to enable marker-assisted selection and introgression of $b c-3$ (Johnson et al. 1997; Kelly et al. 2003; Mukeshimana et al. 2005; Naderpour et al. 2010; Pedrosa-Harand et al. 2008).

Revolutionary advances in the understanding of the molecular genetic and functional basis for resistance to the Potyviridae have led to the conclusion that naturally occurring amino acid substitutions in specific regions of eIF4E and eIF(iso)4E result in the numerous and effective recessive resistance genes common across many important monocot and dicot crop plant-potyvirus pathosystems (see reviews, Diaz-Pendon et al. 2004; Kang et al. 2005a; LeGall et al. 2011; Robaglia and Caranta 2006; Truniger and Aranda 2009; Wang and Krishnaswamy 2012). Recognizing this, eIF4E, eIF(iso)4E, and the novel cap binding protein (nCBP) were cloned and sequenced from a collection of nine common bean genotypes that represented eight different allele combinations of the $I$ and $b c$ - resistance genes (Naderpour et al. 2010). Predicted amino acid substitutions were discovered in a variant of $P$. vulgaris eIF4E (PveIF4E ${ }^{2}$ ), which was cloned exclusively from four genotypes that possessed the $b c-3$ resistance allele. Alignment of PveIF4E ${ }^{2}$ with eIF4E variants that have been confirmed to condition resistance to potyviruses in Capsicum апnиum (Kang et al. 2005b; Ruffel et al. 2002), Lactuca sativa (Nicaise et al. 2003), and Pisum sativum (Gao et al. 2004) revealed analogous features of amino acid substitutions in the predicted cap binding pocket of the protein (Naderpour et al. 2010). A cleaved amplified polymorphic sequence (CAPS) marker diagnostic for PveIF $4 E^{2}$ cosegregated with $b c-3$ conditioned resistance to BCMV strain NL 1 (NL 1) in a segregating $F_{2}$ population of 96 individuals (Naderpour et al. 2010). Though not confirmed by direct complementation testing, these results provided the initial evidence towards mutated eIF4E alleles as the molecular basis for $b c-3$.

In light of the possibility that $b c-3$ resistance to ClYVV may also be confirmed by a mutant eIF4E allele, and the immediate practical need to deploy resistance to CIYVV in the Great Lakes Region of the U.S., a more thorough understanding of the available genetic variation for resistance was needed. The objectives of this research were to evaluate, identify, and characterize the ClYVV resistance present in 21 informative common bean genotypes and establish the allelic relationships of all three previously reported recessive resistance genes to ClYVV (cyv, desc, and bc-3). Subsequent objectives were to further examine the potential association of predicted amino acid substitutions in PveIF4E with resistance to CIYVV and then to develop a set of single nucleotide polymorphism (SNP)-based markers for rapid allelic discrimination and marker-assisted selection of the recessive potyvirus resistance alleles at the $B c-3$ locus.

\section{Materials and methods}

Plant materials and population development

A panel of 21 common bean genotypes was assembled to include entries reported to possess the putatively independent recessive resistance genes to CIYVV (cyv, desc, or bc3) as well as additional entries with known and/or demonstrated virus interaction phenotypes (Table 1). Five of the entries were snap bean genotypes (Baby Bop, Laureat, Paloma, Polder, Sonesta) that were identified to be resistant to ClYVV-NY as the result of a screen of cultivars (Hart and Griffiths, unpublished).

Populations were developed for cosegregation analysis and allelism testing. Midnight, the recurrent susceptible parent used in the development of the ClYVV resistant cultivar Black Knight was crossed to Black Knight to create $F_{1}$ and $F_{2}$ populations for cosegregation analysis. Black Knight is nearly isogenic with Midnight but possesses the cyv resistance allele (Halseth et al. 1998) from GN 1140 (Provvidenti 1987; Provvidenti and Schroeder 1973). Black Knight was also crossed to Raven (Kelly et al. 1994) that possesses the $I, b c-3$ allele combination to develop $\mathrm{F}_{1}$ and $F_{2}$ populations for cosegregation analysis and allelism testing. B/R RIL 105-25, a breeding line developed at Michigan State University (East Lansing, MI) that possesses I, $b c-3$ from Raven was crossed to the ClYVV resistant cultivar Clipper that possesses cyv (Tu 1983) to develop $\mathrm{F}_{1}$, $\mathrm{F}_{2}$, and $\mathrm{F}_{2: 3}$ populations for allelism testing. The breeding line CY-10 $\mathrm{S}_{4}$ was crossed to USWK $\times \mathrm{H} \mathrm{S}_{4}$ to develop $F_{1}$ and $F_{2}$ populations for allelism testing. $\mathrm{CY}-10 \mathrm{~S}_{4}$ is a $\mathrm{BC}_{8} \mathrm{~S}_{4}$ line developed at Cornell University (CU) New York state agricultural experiment station (NYSAES) (Geneva, 
Table 1 Common bean genotypes, sources, market classes, previously reported resistance genes to Clover yellow vein virus (ClYVV), and their respective responses to the NY strain of CIYVV (ClYVV-NY) and the NL 3D strain of Bean common mosaic necrosis virus (NL 3D)

\begin{tabular}{|c|c|c|c|c|c|}
\hline Genotype & Accession $^{a}$ & Market class & $\begin{array}{l}\text { ClYVV } \\
\text { resistance }\end{array}$ & $\begin{array}{l}\text { Response to } \\
\text { ClYVV-NY }\end{array}$ & Response to NL $3 \mathrm{D}^{\mathrm{j}}$ \\
\hline Dubbele Witte & PI 377736 & Fresh snap & - & sS, VN, sM, TN & $\mathrm{S}, \mathrm{Ld}, \mathrm{M}$ \\
\hline Midnight & PI 550032 & Black & - & $\mathrm{sS}, \mathrm{VN}, \mathrm{sM}$ & VN, SN, D \\
\hline Hystyle & PI 550288 & Processing snap & - & sS, VN, sM, TN & VN, SN, D \\
\hline GN 1140 & PI 549667 & Great northern & $c y v^{\mathrm{b}}$ & NS & $\mathrm{mM}$ \\
\hline Black Knight & $\mathrm{CU}$ & Black & $c y v^{\mathrm{c}}$ & NS & VN, SN, D \\
\hline Jolanda & G 7591 & Fresh snap & $\operatorname{desc}^{\mathrm{d}}$ & NS & NLL, VN, Ld, M \\
\hline Amanda & PI 599026 & Fresh snap & $c y v^{\mathrm{e}}$ & NS & lVN \\
\hline Baby bop & PI 642144 & Processing snap & - & NS & VN, SN, D \\
\hline Laureat & PI 550261 & Processing snap & - & NS & VN, SN, D \\
\hline Paloma & $\mathrm{CU}$ & Fresh snap & - & NS & VN, SN, D \\
\hline Polder & $\mathrm{CU}$ & Fresh snap & - & NS & VN, SN, D \\
\hline Sonesta & $\mathrm{CU}$ & Fresh snap (wax) & - & NS & VN, SN, D \\
\hline Imuna & PI 326420 & Fresh snap & $c y v^{\mathrm{e}}, \operatorname{desc} c^{\mathrm{d}}$ & NS & $\mathrm{mM}$ \\
\hline Evolutie & W6 42706 & Fresh snap & $d e s c^{\mathrm{d}}$ & NS & VN, SN, D \\
\hline Clipper & PI 278776 & Navy & $c y v^{\mathrm{f}}$ & NS & $\mathrm{S}, \mathrm{Ld}, \mathrm{M}$ \\
\hline CY-10 $\mathrm{S}_{4}$ & $\mathrm{CU}$ & Processing snap & $c y v$ & NS & VN, SN, D \\
\hline IVT 7214 & PI 602987 & Expt. line & $b c-3^{\mathrm{g}}$ & NS & NS \\
\hline Raven & MSU & Black & $b c-3^{\mathrm{h}}$ & NS & NS \\
\hline B/R RIL105-25 & MSU & Navy & $b c-3$ & NS & NS \\
\hline USWK-6 & PI 618815 & White kidney & $b c-3^{\mathrm{i}}$ & NS & NS \\
\hline $\mathrm{USWKH} \times \mathrm{H} \mathrm{S}_{4}$ & $\mathrm{CU}$ & Expt. line & $b c-3$ & NS & NS \\
\hline
\end{tabular}

a Accessions that begin with 'PI' and 'W6' were sourced from the U.S. National Plant Germplasm System, 'G' international center for tropical agriculture, 'CU' Cornell University, and 'MSU' Michigan State University

Resistance genes cited in the following references: ${ }^{\mathrm{b}}$ Provvidenti and Schroeder 1973, ${ }^{\mathrm{c}}$ Halseth et al. 1998, ${ }^{\mathrm{d}}$ Sato et al. 2003 , ${ }^{\mathrm{e}}$ Park and Tu $1991,{ }^{\mathrm{f}}$ Tu 1983, ${ }^{\mathrm{g}}$ Drijfhout $1978,{ }^{\mathrm{h}}$ Kelly et al. $1994,{ }^{\mathrm{i}}$ Miklas et al. 2002

j Symptom legend: $D$ plant death, $L d$ leaf distortion, $M$ mosaic, $m M$ mild mosaic, $s M$ severe mosaic, $N L L$ necrotic local lesions, $N S$ no symptoms, $S$ stunting, $s S$ severe stunting, $S N$ systemic necrosis, $V N$ vein necrosis, $l V N$ localized vein necrosis

NY) through the introgression of cyv from Clipper into the susceptible recurrent parent Hystyle. USWKH x $\mathrm{H}$ $\mathrm{S}_{4}$ is a $\mathrm{BC}_{2} \mathrm{~S}_{4}$ line developed at $\mathrm{CU}$ through introgression of $b c-3$ from USWK-6 into the susceptible recurrent parent Hystyle. USWK-6 is a breeding line developed by the USDA-ARS that possesses $I, b c$-3 (Miklas et al. 2002).

Additional $\mathrm{F}_{1}$ populations were developed to investigate allelic relationships through complementation testing. Amanda (cyv) was crossed to Imuna (cyv/desc) and Jolanda (desc) was crossed to Clipper (cyv) to develop $\mathrm{F}_{1}$ populations. All $\mathrm{F}_{1}$ hybrid plants were confirmed heterozygous by morphology, by allele-specific molecular marker assays, or both. The molecular marker assays are described in the 'sequence analysis and design of allele-specific assays' section of the methods below.

Seeds of all experimental material were sown in 'Cornell mix' (Boodley and Sheldrake 1972) in greenhouses at CU NYSAES, where routine watering, fertilization, and insect control measures were employed. Plant growth conditions were $24{ }^{\circ} \mathrm{C}$ day $/ 21{ }^{\circ} \mathrm{C}$ night with a 14 -h photoperiod.
Supplemental lighting was produced by $1,000 \mathrm{~W}$ metal halide bulbs (SunSystem III, Sunlight Supply, Inc., USA) to provide a rate of $300 \mu \mathrm{M} \mathrm{m} \mathrm{s}^{1}$ of photosynthetically active radiation at bench level. All of the plants used in the experiments were grown in $14.6 \mathrm{~cm}^{2}$ pots except for the $\mathrm{F}_{2}$ derived $\mathrm{F}_{3}$ families $\left(\mathrm{F}_{2: 3}\right)$ which were grown in 18 cell flats (Speedling Inc., USA) with cells of $10 \mathrm{~cm}^{2}$.

Virus isolates, inoculation, and resistance evaluation

ClYVV-NY was obtained from the Rosario Provvidenti collection at CU NYSAES and confirmed to be a pure isolate by host range and symptomatology, and RT-PCR (Provvidenti and Schroeder 1973; Shail et al. 2007). The reaction of the common bean BCMV/BCMNV host differential groups and genotypes to ClYVV-NY is presented in Online Resource 1, Table 1. ClYVV-NY is identical to the strain employed by Larsen et al. (2008). ClYVV-NY was maintained in the susceptible snap bean cultivar Hystyle. The NL 3D strain (Drijfhout 1978; Larsen et al. 2005) was obtained 
from Dr. Phillip Miklas of the USDA-ARS (Prosser, WA) and was maintained in the cultivar Dubbele Witte. The virus strains were maintained by periodical transfer ( $\sim 3$ weeks) to the expanding primary leaves of seedlings of the susceptible cultivars by mechanical inoculation. Virus inoculum was prepared by homogenizing newly expanded, symptomatic, virus-infected trifoliate leaves $(1: 10 \mathrm{w} / \mathrm{v})$ in cold $10 \mathrm{mM}$ phosphate buffer ( $3 \mathrm{mM} \mathrm{K}_{2} \mathrm{PO}_{4}, 7 \mathrm{mM} \mathrm{Na}_{2} \mathrm{HPO}_{4} ; \mathrm{pH}$ 7.0) with a mortar and pestle. The homogenate was applied with the pestle by gently rubbing newly expanded primary leaves of seedlings (7-10 days after planting) that had been dusted with carborundum (silicon carbide, 400 mesh, SigmaAldrich Inc., USA). The inoculated plants were then lightly rinsed with water. All plants were inoculated again 2 days after the first inoculation, and plants that did not display virus symptoms 10 days post the first inoculation (dpi) were re-inoculated to prevent escape.

At least 20 inoculated plants of each of the 21 genotypes included in the panel were inoculated and evaluated in three separate experiments. The plants were examined daily for virus symptoms, and symptom expression was evaluated in comparison to non-inoculated, susceptible, and resistant controls, and recorded 10, 21, 30, and 45 dpi. Symptom expression in response to inoculation with CIYVV-NY and NL 3D was evaluated qualitatively following the descriptors defined in the caption of Table 1 . At $21 \mathrm{dpi}$, leaf tissue from newly expanded trifoliate leaves was collected for virus detection by enzyme-linked immunosorbent assay (ELISA). The ELISA was performed according to the manufacturer's instructions (for ClYVV-NY:ClYVV-C81 and Pratt, AC Diagnostics Inc., USA; for NL 3D: Potyvirus Group, Agdia Inc., USA). The absorbance at $\mathrm{OD}_{405 \mathrm{~nm}}$ was measured with a multi-mode microplate reader (Synergy 2, Biotek Instruments Inc., USA) following the final incubation and after two additional 1-h intervals. Absorbance reads that were at least two times greater than that of the healthy negative control were considered to be positive for presence of the virus.

\section{Cloning and sequencing of $P$. vulgaris eIF4E}

Coding sequences of PveIF4E for each genotype in Table 1 were obtained as follows. Total RNA was isolated with an Ambion RNAqueous-4PCR Kit (Life Technologies, USA) following the manufacturer's instructions. The RNA was eluted into $30 \mu \mathrm{L}$ of elution buffer and quantified by spectrophotometry so that $1 \mu \mathrm{g}$ of RNA could be used for cDNA synthesis. Reverse transcription was performed with an Ambion RETROscript First Strand Synthesis Kit following the manufacturer's instructions (Life Technologies, USA). Oligonucleotide primers capable of amplifying the entire PveIF4E coding sequence were designed prior to the release of the $P$. vulgaris genome sequence and thus were designed to anneal to the extremities of the eIF4E coding sequences of pea (Pisum sativum L.) and soybean (Glycine $\max (\mathrm{L}$.) Merr.). The primer pair was designed using Primer 3 (Rozen and Skaletsky 2000); the forward primer was designated Leg4E-F (5'-ATG GTT GTA GAA GAT ACC C- $3^{\prime}$ ) and the reverse primer, Leg4E-R (5'-TCA TAC AAC GTA TTT ATT TTT AGC-3'). PCR amplification was performed in $20 \mu \mathrm{L}$ reactions containing $0.5 \mu \mathrm{L}$ of cDNA, 5 pmol of each primer, and 1.5 units of Platinum ${ }^{\circledR}$ Taq DNA Polymerase High Fidelity (Life Technologies, USA) using an Eppendorf Gradient Master Cycler (Eppendorf North America, USA). The PCR program consisted of 1 denaturation cycle of $3 \mathrm{~min}$ at $95^{\circ} \mathrm{C}$ followed by 40 cycles of $30 \mathrm{~s}$ each of 94,53 , and $72{ }^{\circ} \mathrm{C}$. Aliquots of the PCR products were resolved by $1.5 \%$ TAE agarose gel electrophoresis and visualized with ethidium bromide under UVlight to confirm that amplicons had the expected size of $693 \mathrm{bp}$. PCR products were then purified using a QIAquick PCR purification kit (Qiagen Inc., USA).

Two independently amplified PCR products from each genotype were cloned into the $\mathrm{pCR} 4$ vector using the TOPO TA Cloning Kit for Sequencing (Life Technologies, USA). DNA was isolated from liquid cultures of two single colony clones in selective media using the QIAprep Spin Miniprep kit (Qiagen Inc., USA). Nucleotide sequencing was performed with an Applied Biosystems Automated 3730 DNA Analyzer using Big Dye Terminator chemistry and AmpliTaq-FS DNA Polymerase (Life Technologies, USA) at the CU Life Sciences Core Laboratories Center, Ithaca, NY.

Sequence analysis and design of allele-specific assays

The PveIF4E coding sequences and deduced proteins were aligned to detect non-synonymous SNPs and amino acid substitutions. Multiple sequence alignment by ClustalW was performed with the CLC Main Workbench (CLC Bio, USA) software. PveIF4E coding sequences were also aligned to the Glycine $\max$ (L.) Merr. genomic sequence (Schmutz et al. 2010) with the 'est2genome' model of the Exonerate multiple sequence alignment program (Slater and Birney 2005) to predict the intron-exon boundaries of PveIF4E. Non-synonymous SNPs that corresponded with defined virus resistance phenotypes were chosen for the design of KBiosciences Competitive Allele-Specific PCR (KASPar) SNP assays (LGC-KBiosciences, USA) (Fig. 1). At least $50 \mathrm{bp}$ of sequence flanking both sides of the targeted SNPs was submitted to the KBiosciences KASPar By Design service and the primers in Table 2 were synthesized for the assays.

\section{DNA extraction and KASPar assays}

Genomic DNA for use in KASPar assays was isolated from $\sim 50 \mathrm{mg}$ of tissue from young trifoliate leaves according 


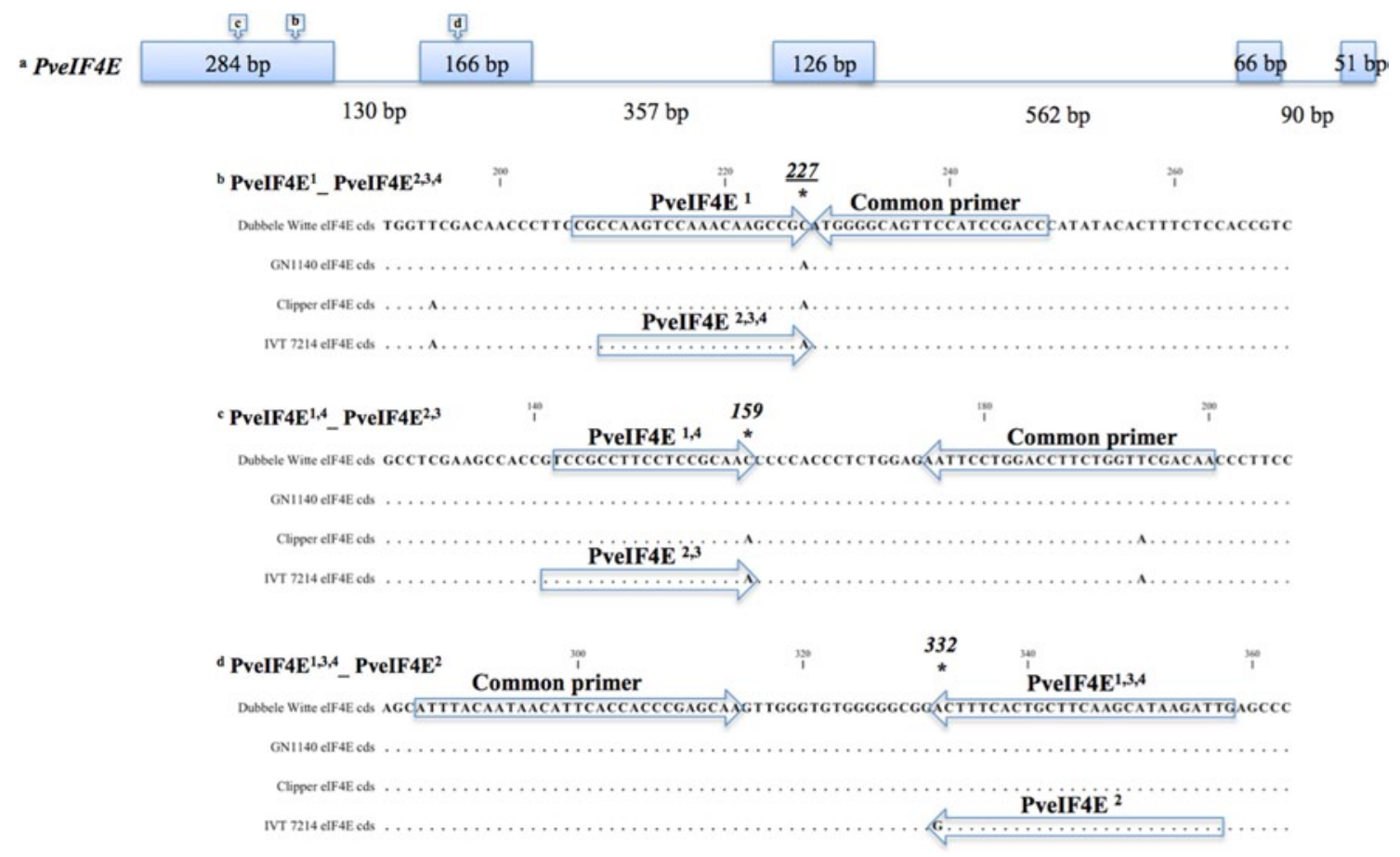

Fig. 1 Schematic of genomic PveIF4E where boxes correspond to exons, lines correspond to introns, and the relative positions of the non-synonymous SNPs targeted for the development of KAS-
Par assays are indicated by boxes with arrows. The KASPar assays described in Table 2 are illustrated below

Table 2 Assay ID, target SNPs, and primer sequences of the KASPar assays employed

\begin{tabular}{|c|c|c|c|}
\hline KASPar assay ID & SNP & Primer & Sequence \\
\hline PveIF4E $^{1}$ _PveIF4E ${ }^{2,3,4}$ & C227A & $\begin{array}{l}\text { PveIF4E }^{1} \text { Allele (C_VIC) } \\
\text { PveIF4E }{ }^{2,3,4} \text { Allele (A_FAM) } \\
\text { Common }\end{array}$ & $\begin{array}{l}\text { CGCCAAGTCCAAACAAGCCGC } \\
\text { CGCCAAGTCCAAACAAGCCGA } \\
\text { GGTCGGATGGAACTGCCCCAT }\end{array}$ \\
\hline PveIF4E $^{1,4}{ }_{\text {PveIF4E }}{ }^{2,3}$ & C159A & $\begin{array}{l}\text { PveIF4E }{ }^{1,4} \text { Allele (C_VIC) } \\
\text { PveIF4E }{ }^{2,3} \text { Allele (A_FAM) } \\
\text { Common }\end{array}$ & $\begin{array}{l}\text { GTCCGCCTTCCTCCGCAAC } \\
\text { CGTCCGCCTTCCTCCGCAAA } \\
\text { TGTCGAACCAGAAGGTCCAGGAATT }\end{array}$ \\
\hline PveIF4E $^{1,3,4}$ PveIF4E $^{2}$ & A332G & $\begin{array}{l}\text { PveIF4E }{ }^{1,3,4} \text { Allele }\left(\mathbf{A}_{-} \text {VIC) }\right. \\
\text { PveIF4E }{ }^{2} \text { Allele (G_FAM) } \\
\text { Common }\end{array}$ & $\begin{array}{l}\text { CAATCTTATGCTTGAAGCAGTGAAAGT } \\
\text { AATCTTATGCTTGAAGCAGTGAAAGC } \\
\text { ATTTACAATAACATTCACCACCCGAGCA }\end{array}$ \\
\hline
\end{tabular}

to Afanador et al. (1993). DNA was checked for purity by spectrophotometry (NanoDrop ND-1000, Thermo Scientific, USA) and was quantified using Quant-iT PicoGreen (Life Technologies, USA) and a multi-mode microplate reader (Synergy 2, Biotek Instruments Inc., USA). DNA was diluted with nuclease free water to $5 \mathrm{ng} / \mu \mathrm{L}$. KASPar assays were performed according to the manufacturer's instructions (Robinson and Holmes, 2011) in $8 \mu \mathrm{L}$ reaction volumes containing $4 \mu \mathrm{L}$ of DNA, $4 \mu \mathrm{L}$ of $2 \times$ KASP reaction mix, and $0.11 \mu \mathrm{L}$ of the assay mix containing the common primer and the fluor-labeled allele-specific primers. PCR amplification consisted of one $15 \mathrm{~min}$ cycle at
$94{ }^{\circ} \mathrm{C}$, followed by 10 cycles of $94{ }^{\circ} \mathrm{C}$ for $20 \mathrm{~s}, 65-57{ }^{\circ} \mathrm{C}$ for $60 \mathrm{~s}$ (dropping $0.8{ }^{\circ} \mathrm{C}$ per cycle), and then 30 cycles of $94{ }^{\circ} \mathrm{C}$ for $20 \mathrm{~s}$, and $57{ }^{\circ} \mathrm{C}$ for $60 \mathrm{~s}$ using an Eppendorf Gradient Master Cycler PCR machine (Eppendorf, USA). Fluorescent endpoint analysis was performed with a ViiA7 Real-Time PCR system (Life Technologies, USA). Fluorescent endpoint analysis data were analyzed with the 'genotyping experiment' module of the ViiA7 Software package (Life Technologies, USA) and allele calls were assigned to the samples automatically by the software. In some cases, interaction with the software to infer an allele call, or to remove a failed reaction, was necessary. 


\section{Results}

Allelism tests demonstrated that $c y v, d e s c$, and $b c-3$ are allelic

The lack of symptoms (Table 1) and negative ELISA results (data not shown) confirmed that the genotypes included in the panel that possessed $c y v$, desc, and $b c-3$ all conditioned resistance to CIYVV-NY. These results validated the use of ClYVV-NY to evaluate potential allelic relationships. All $F_{1}, F_{2}$, and $F_{2: 3}$ populations derived from the crosses between CIYVV resistant parents possessing either cyv, $d e s c$, or $b c-3$ were uniformly resistant based on the absence of symptoms (Table 3) and negative ELISA results. In total, 90 individuals from five separate $F_{1}$ populations, 289 individuals from two separate $\mathrm{F}_{2}$ populations, and $132 \mathrm{~F}_{2: 3}$ lines (1,188 individuals) were resistant to ClYVV-NY. The failure of complementation to restore susceptibility provides clear evidence that $c y v$, desc, and $b c-3$ are allelic and, therefore, map to the same genetic locus on chromosome 6 .

Resistance to ClYVV-NY in $P$. vulgaris is associated with an allelic series at PveIF4E

The complete coding sequences of PveIF4E were obtained from each of the 21 genotypes in Table 1 and were examined for non-synonymous single nucleotide polymorphisms (Table 4; for full-length alignment see Online Resource 1). The Leg4E primer pair produced a single amplicon of the expected size of 693 bp for all cDNA templates. BLASTn and BLASTp (http://blast.ncbi.nlm.nih.gov/) queries of the sequenced amplicons and the predicted amino acid sequences from Dubbele Witte and Raven confirmed identity with PveIF4E $E^{l}$ (EF571267) and PveIF4E ${ }^{2}$ (EF571273), respectively, previously cloned and sequenced from the same genotypes (Naderpour et al. 2010). This gene corresponds to the locus Phvul.006G168400 on chromosome six of the V1.0 release of the P. vulgaris genome (Phaseolus vulgaris V1.0 2013).

The complete PveIF4E coding sequences from Midnight and Hystyle, two genotypes (in addition to Dubbele Witte) that were susceptible to ClYVV-NY, and displayed the unprotected $I$ gene response of systemic necrosis to NL 3D (Kelly et al. 1995), were identical to PveIF4E ${ }^{l}$. The complete PveIF4E coding sequences from IVT 7214, B/R RIL 105-25, USWK-6, and USWKH x H S , four genotypes (in addition to Raven) that were resistant to ClYVV-NY and NL 3D as conditioned by $b c-3$ were identical to PveIF $4 E^{2}$. $P$ veIF $4 E^{2}$ differed from $P$ veIF $4 E^{l}$ by four SNPs that each resulted in predicted amino acid substitutions at positions $53(\mathrm{~N} / \mathrm{K}), 65(\mathrm{~F} / \mathrm{Y}), 76(\mathrm{~A} / \mathrm{E})$, and $111(\mathrm{D} / \mathrm{G})$ of the predicted protein (Table 4). PveIF4E ${ }^{2}$ was associated with homozygous recessive resistance to NL 1 as conditioned by the $b c-3$ gene in previous cosegregation analysis (Naderpour et al. 2010).

Two novel PveIF4E mutant alleles were identified, $P v e I F 4 E^{3}$, and PveIF4E $E^{4}$, that were identical for some, but not all of the SNPs and predicted amino acid substitutions
Table 3 Resistance to ClYVV-NY in common bean parental genotypes and populations tested for allelism

\footnotetext{
a 9 plants per F2:3 line tested
}

\begin{tabular}{|c|c|c|c|c|}
\hline Genotype & ClYVV resistance & Population & $\begin{array}{l}\text { No. plants/ } \\
\text { lines }\end{array}$ & $\begin{array}{l}\text { Phenotype } \\
\text { (ClYVV-NY) }\end{array}$ \\
\hline Clipper & cyv & Parent 1 & 18 & Resistant \\
\hline B/R RIL 105-25 & $b c-3$ & Parent 2 & 18 & Resistant \\
\hline Clipper $\times$ B/R RIL 105-25 & $c y v b c-3$ & $\mathrm{~F}_{1}$ & 18 & Resistant \\
\hline Clipper $\times$ B/R RIL 105-25 & & $\mathrm{F}_{2}$ & 132 & Resistant \\
\hline Clipper $\times$ B/R RIL 105-25 & & $\mathrm{F}_{2: 3}$ & $132^{\mathrm{a}}$ & Resistant \\
\hline CY-10 $\mathrm{S}_{4}$ & cyv & Parent 1 & 18 & Resistant \\
\hline USWKH $\times \mathrm{H} \mathrm{S}_{4}$ & $b c-3$ & Parent 2 & 18 & Resistant \\
\hline $\mathrm{CY}-10 \mathrm{~S}_{4} \times \mathrm{USWKH} \times \mathrm{H} \mathrm{S}_{4}$ & $c y v b c-3$ & $\mathrm{~F}_{1}$ & 18 & Resistant \\
\hline $\mathrm{CY}-10 \mathrm{~S}_{4} \times \mathrm{USWKH} \times \mathrm{H} \mathrm{S}_{4}$ & & $\mathrm{~F}_{2}$ & 157 & Resistant \\
\hline Black Knight & Cyv & Parent 1 & 18 & Resistant \\
\hline Raven & $b c-3$ & Parent 2 & 18 & Resistant \\
\hline Black Knight $\times$ Raven & $c y v b c-3$ & $\mathrm{~F}_{1}$ & 18 & Resistant \\
\hline Black Knight $\times$ Raven & & $\mathrm{F}_{2}$ & 40 & Resistant \\
\hline Amanda & $c y v$ & Parent 1 & 18 & Resistant \\
\hline Imuna & $\operatorname{cyv}(\operatorname{desc})$ & Parent 2 & 18 & Resistant \\
\hline Amanda $\times$ Imuna & $\operatorname{cyv} \operatorname{cyv}(\operatorname{desc})$ & $\mathrm{F}_{1}$ & 18 & Resistant \\
\hline Jolanda & desc & Parent 1 & 18 & Resistant \\
\hline Clipper & $c y v$ & Parent 2 & 18 & Resistant \\
\hline Jolanda $\times$ Clipper & $\operatorname{desc} c y v$ & $\mathrm{~F}_{1}$ & 18 & Resistant \\
\hline
\end{tabular}


Table 4 Resistance of 21 common bean genotypes to CIYVV-NY and NL 3D and their corresponding nucleotide polymorphisms and predicted amino acid substitutions in PveIF4E

\begin{tabular}{|c|c|c|c|c|c|c|c|c|c|c|c|}
\hline \multirow[t]{3}{*}{ Genotype } & \multirow[t]{3}{*}{ ClYVV-NYa } & \multirow[t]{3}{*}{ NL 3 $\mathrm{D}^{\mathrm{a}}$} & \multicolumn{8}{|c|}{$\begin{array}{l}\text { Position of nucleotide (nt) polymorphism and amino acid (aa) } \\
\text { substitutions }{ }^{\mathrm{b}}\end{array}$} & \multirow[t]{3}{*}{$P v e I F 4 E$ alleles ${ }^{c}$} \\
\hline & & & $\mathrm{nt}$ & aa & $\mathrm{nt}$ & $\mathbf{a a}$ & nt & aa & $\mathrm{nt}$ & aa & \\
\hline & & & 159 & 53 & 194 & 65 & 227 & 76 & 332 & 111 & \\
\hline Dubbele Witte & $\mathrm{S}$ & $\mathrm{S}$ & $\mathrm{C}$ & $\mathbf{N}$ & $\mathrm{T}$ & $\mathbf{F}$ & $\mathrm{C}$ & A & A & D & PveIF4E ${ }^{I(\mathrm{~d})}$ \\
\hline Midnight & $\mathrm{S}$ & $\mathrm{S}$ & - & - & - & - & - & - & - & - & \\
\hline Hystyle & $\mathrm{S}$ & $\mathrm{S}$ & - & - & - & - & - & - & - & - & \\
\hline GN 1140 & $r(c y v)$ & $\mathrm{S}$ & - & - & - & - & A & $\mathbf{E}$ & - & - & PveIF $4 E^{4}$ \\
\hline Black Knight & $r(c y v)$ & SN & - & - & - & - & A & $\mathbf{E}$ & - & - & \\
\hline Jolanda & $r(\operatorname{desc})$ & VN & - & - & - & - & A & $\mathbf{E}$ & - & - & \\
\hline Amanda & $r(c y v)$ & VN & - & - & - & - & A & $\mathbf{E}$ & - & - & \\
\hline Baby Bop & $r$ & SN & - & - & - & - & A & $\mathbf{E}$ & - & - & \\
\hline Laureat & $r$ & SN & - & - & - & - & A & $\mathbf{E}$ & - & - & \\
\hline Paloma & $r$ & SN & - & - & - & - & A & $\mathbf{E}$ & - & - & \\
\hline Polder & $r$ & SN & - & - & - & - & A & $\mathbf{E}$ & - & - & \\
\hline Sonesta & $r$ & $\mathrm{SN}$ & - & - & - & - & A & $\mathbf{E}$ & - & - & \\
\hline Imuna & $r($ cyv/desc $)$ & $\mathrm{S}$ & A & $\mathbf{K}$ & A & $\mathbf{Y}$ & A & $\mathbf{E}$ & - & - & PveIF $4 E^{3}$ \\
\hline Evolutie & $r(\operatorname{desc})$ & SN & A & $\mathbf{K}$ & A & $\mathbf{Y}$ & A & $\mathbf{E}$ & - & - & \\
\hline Clipper & $r(\operatorname{cyv})$ & $\mathrm{S}$ & A & $\mathbf{K}$ & A & $\mathbf{Y}$ & A & $\mathbf{E}$ & - & - & \\
\hline CY-10 $\mathrm{S}_{4}$ & $r(c y v)$ & SN & A & $\mathbf{K}$ & A & $\mathbf{Y}$ & A & $\mathbf{E}$ & - & - & \\
\hline IVT 7214 & $r(b c-3)$ & $r(b c-3)$ & A & $\mathbf{K}$ & A & $\mathbf{Y}$ & A & $\mathbf{E}$ & $\mathrm{G}$ & G & PveIF4E ${ }^{2(\mathrm{e})}$ \\
\hline Raven & $r(b c-3)$ & $r(b c-3)$ & A & $\mathbf{K}$ & A & $\mathbf{Y}$ & A & $\mathbf{E}$ & $\mathrm{G}$ & $\mathbf{G}$ & \\
\hline B/R RIL105-25 & $r(b c-3)$ & $r(b c-3)$ & A & $\mathbf{K}$ & A & $\mathbf{Y}$ & A & $\mathbf{E}$ & $\mathrm{G}$ & $\mathbf{G}$ & \\
\hline USWK-6 & $r(b c-3)$ & $r(b c-3)$ & A & $\mathbf{K}$ & A & $\mathbf{Y}$ & A & $\mathbf{E}$ & $\mathrm{G}$ & $\mathbf{G}$ & \\
\hline $\mathrm{USWKH} \times \mathrm{HS}_{4}$ & $r(b c-3)$ & $r(b c-3)$ & A & $\mathbf{K}$ & A & $\mathbf{Y}$ & A & $\mathbf{E}$ & $\mathrm{G}$ & $\mathbf{G}$ & \\
\hline
\end{tabular}

a $S$ susceptible, $S N$ systemic necrois, $V N$ vein necrosis, $r$ resistant; confirmed by screening 5 to 10 plants of each cultivar in three independent experiments, with ' $r$ ' confirmed by ELISA

${ }^{\mathrm{b}}$ A dash (-) in the table represents an identical nt or aa as PveIF4E1

${ }^{c} P$ veIF4E alleles are numbered by superscript in the order in which they were discovered

d PveIF4E1 first cloned and sequenced from Dubbele Witte and others in Naderpour et al. 2010

e PveIF4E2 first cloned and sequenced from Raven in Naderpour et al. 2010

of PveIF4E ${ }^{2}$ (Table 4). These novel mutant alleles were exclusive to genotypes with resistance to ClYVV-NY and susceptibility to NL 3D. PveIF4E $E^{3}$ first cloned and sequenced from Clipper, also present in CY-10 $\mathrm{S}_{4}$, Evolutie, and Imuna, possessed three of the four predicted amino acid substitutions present in $P$ veIF $4 E^{2}$ at positions 53 (N/K), 65 (F/Y), and 76 (A/E), respectively. PveIF4E ${ }^{4}$, first cloned and sequenced from GN 1140, also present in Black Knight, Jolanda, Amanda, Baby Bop, Laureat, Paloma, Polder, and Sonesta, possessed only one of the four predicted amino acid substitutions present in PveIF4E ${ }^{2}$ at position 76 (A/E). This result strongly suggests that the A76E mutation is a determinant for resistance to ClYVV-NY.

Only genotypes that possessed PveIF4E $E^{2}$ and the predicted D111G mutation were resistant to NL 3D (Table 4). Similarly, this result strongly suggests that the D111G mutation is a determinant for resistance to NL 3D. The pattern of exclusive non-synonymous nucleotide substitutions present in PveIF4E ${ }^{2}$, PveIF $4 E^{3}$, and PveIF4E ${ }^{4}$ are analogous to the patterns of polymorphism in the critical area of eIF4E for cap-binding and recognition where amino acid substitutions have been associated with, or directly demonstrated to condition potyvirus resistance in an extensive range of crop plants (Diaz-Pendon et al. 2004; Kang et al. 2005a; LeGall et al. 2011; Robaglia and Caranta 2006; Truniger and Aranda 2009; Wang and Krishnaswamy 2012).

Allele-specific genotyping and cosegregation analysis

In order to progress from polymorphism discovery to allele-specific molecular markers as rapidly as possible, 
three KASPar SNP genotyping assays were developed to differentiate and confirm the allelic state of all of the PveIF4E alleles (Table 2). The assays were employed to investigate genotype-phenotype relationships, to confirm allelism, and to validate the utility of the assays for allelic discrimination across the germplasm.

KASPar assay 'PveIF4E'__PveIF4E ${ }^{2,3,4}$ ' targets the SNP227 (C227A) mutation that corresponds to the predicted A76E amino acid substitution that is present in the PveIF4E $E^{2,3,4}$ alleles, all associated with resistance to ClYVV-NY (Table 4). This assay was employed to investigate genotype-phenotype relationships in parental, $\mathrm{F}_{1}$, and $\mathrm{F}_{2}$ populations of the Midnight $\times$ Black Knight cross (Table 5). An example of the allele calls made by the software is illustrated in Online Resource 1, Fig. 4, for 88 Midnight $\times$ Black Knight $F_{2}$ individuals. The genotypic and phenotypic segregation ratios fit that expected of a single recessive locus, and the homozygous state of the mutant allele (AA) was in complete linkage with the resistance phenotype in $49 \mathrm{~F}_{2}$ individuals (Table 5).

KASPar assay 'PveIF4E ${ }^{1,3,4}$ _PveIF4E' ${ }^{2}$ ' targets the SNP332 (A332G) mutation that corresponds to the predicted D111G amino acid substitution present only in PveIF4E $E^{2}$ and that is associated with $b c-3$ resistance to ClYVV-NY, ClYVV-WI (Larsen et al. 2008), NL 3D, and NL 1 (Naderpour et al. 2010) (Table 4). This assay was employed to investigate genotype-phenotype relationships in the parental, $\mathrm{F}_{1}$, and $\mathrm{F}_{2}$ populations of the Black Knight $\times$ Raven cross (Table 6 ). The genotypic and phenotypic segregation ratios fit that expected for a single recessive locus, and the homozygous state of the mutant allele (GG) was in complete linkage with the resistance phenotype in $50 \mathrm{~F}_{2}$ individuals (Table 6).

KASPar assay 'PveIF4E $\mathrm{E}^{1,3,4}$ _PveIF4E' ${ }^{2}$ (A332G) was also employed to demonstrate its ability to discriminate alleles at the molecular genetic level in the parental, $F_{1}$, and $\mathrm{F}_{2}$ allelism testing populations of the Clipper $\mathrm{x}$ B/R RIL 105-25 cross where all phenotypes were identical (Table 7).
The genotypic segregation ratio fit the expectation of a single locus (Table 7). The phenotypic segregation ratio could not be ascertained because the population was inoculated and evaluated only for resistance to ClYVV-NY. KASPar assay 'PveIF4E' ${ }^{1,4}$ PveIF4E $^{2,3}$ ' (C159A) was designed for the purposes of allelic discrimination and haplotype analysis.

The KASPar assays were employed for haplotype analysis across the 21 common bean genotypes. Table $8 \mathrm{dem}$ onstrates the assays' ability to discriminate between the PveIF4E alleles and to ultimately predict the resistance allele and spectrum. The KASPar assays consistently and accurately identified the correct haplotypes for all of the PveIF4E alleles.

\section{Discussion}

The germplasm evaluation (Table 1), the allelism testing (Table 3), the complete association between unique nonsynonymous SNPs in PveIF4E alleles and resistance to CIYVV and/or NL 3D (Table 4), and the KASPar allelespecific assays (Tables $5,6,7,8$ ) all contribute to the evidence that $c y v$, desc, and $b c-3$ comprise a series of recessive resistance alleles at the $B c-3$ locus. This allelic series conditions strain- and species-specific resistance spectra to the potyviruses ClYVV, BCMV, and BCMNV in common bean. In light of this, the nomenclature for the $B c-3$ locus should be revised in accordance with the guidelines for gene nomenclature set forth by the Bean Improvement Cooperative (BIC) (Porch 2012).

The first genetic symbol designated to an allele at this locus was by-3, identified in GN1140 (Provvidenti and Schroeder 1973), although it was subsequently revised to cyv (Provvidenti 1987). It was previously demonstrated that desc from Jolanda was allelic with the ClYVV resistance present in the cultivar Imuna (previously reported as cyv (Park and Tu 1991)) (Sato et al. 2003). We also demonstrate

Table 5 Cosegregation of KASPar SNP PveIF4E ${ }^{1}(\mathbf{C})$ allele with susceptibility and KASPar SNP PveIF4E $\mathrm{E}^{2,3,4}$ (A) allele with resistance to CIYVV-NY as conditioned by cyvcyv in the Midnight x Black Knight populations

\begin{tabular}{|c|c|c|c|c|c|c|}
\hline Genotype & Population & $\begin{array}{l}\text { ClYVV } \\
\text { resistance }\end{array}$ & $\begin{array}{l}\text { PveIF4E }^{1} \_ \text {PveIF4E } \\
\text { SNP (C227A })\end{array}$ & No. & Phenotype $^{b}$ & No. \\
\hline Midnight & Parent 1 & Cуv Cyv & PveIF4E $^{1}(\mathbf{C})$ PveIF $4 E^{1}(\mathbf{C})$ & 18 & Susceptible & 18 \\
\hline Black Knight & Parent 2 & cyvcyv & PveIF4E $^{4}$ (A) PveIF4E ${ }^{4}$ (A) & 18 & Resistant & 18 \\
\hline Midnight $\times$ Black Knight & $\mathrm{F}_{1}$ & Cyvcyv & PveIF4E $^{1}$ (C) PveIF4E Pa) $^{4}$ (A) & 18 & Susceptible & 18 \\
\hline \multirow[t]{3}{*}{ Midnight $\times$ Black Knight } & $\mathrm{F}_{2}$ & cyvcyv & PveIF4E $^{4}$ (A) PveIF4E ${ }^{4}$ (A) & 49 & Resistant & 49 \\
\hline & & Cyvcyv & 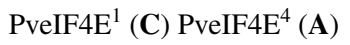 & 97 & Susceptible & 144 \\
\hline & & $C y v C y v$ & PveIF4E $^{1}(\mathbf{C})$ PveIF4E $^{1}(\mathbf{C})$ & 47 & & \\
\hline
\end{tabular}

\footnotetext{
${ }^{a}$ Expected genotypic ratio for $\mathrm{F} 2$ population of $1 \mathrm{AA}: 2 \mathrm{AC}: 1 \mathrm{CC} ; \chi^{2}=0.046, P=0.977(d f=2)$

b Expected phenotypic ratio for F2 population of 1 resistant: 3 susceptible; $\chi^{2}=0.015, P=0.902(d f=1)$
} 
Table 6 Cosegregation of KASPar SNP PveIF4E $E^{1,3,4}(\mathbf{A})$ allele with systemic necrosis and KASPar SNP PveIF4E ${ }^{2}(\mathbf{G})$ allele with resistance to NL $3 \mathrm{D}$ as conditioned by $b c-3$ in the Black Knight $\times$ Raven populations

\begin{tabular}{|c|c|c|c|c|c|c|}
\hline Genotype & Population & $\begin{array}{l}\text { NL 3D } \\
\text { resistance }\end{array}$ & $\begin{array}{l}\text { PveIF4E }^{1,3,4} \_ \text {PveIF4E }^{2} \\
\text { SNP (A332G) }\end{array}$ & No. ${ }^{a}$ & Phenotype $^{\mathrm{b}}$ & No. $^{b}$ \\
\hline Black Knight & Parent 1 & cyvcyv & PveIF4E $^{1,3,4}$ (A) PveIF4E ${ }^{1,3,4}$ (A) & 18 & SN & 18 \\
\hline Raven & Parent 2 & $b c-3 b c-3$ & PveIF4E $^{2}(\mathbf{G})$ PveIF4E $^{2}(\mathbf{G})$ & 18 & Resistant & 18 \\
\hline Black Knight $\times$ Raven & $\mathrm{F}_{1}$ & $c y v b c-3$ & PveIF4E $E^{1,3,4}$ (A) PveIF4E ${ }^{2}$ (G) & 18 & SN & 18 \\
\hline \multirow[t]{3}{*}{ Black Knight $\times$ Raven } & \multirow[t]{3}{*}{$\mathrm{F}_{2}$} & $b c-3 b c-3$ & PveIF4E $^{2}$ (G) PveIF4E ${ }^{2}(\mathbf{G})$ & 50 & Resistant & 50 \\
\hline & & $c y v b c-3$ & PveIF4E $E^{1,3,4}$ (A) PveIF4E ${ }^{2}$ (G) & 84 & SN & 134 \\
\hline & & cyvcyv & PveIF4E $^{1,3,4}$ (A) PveIF4E ${ }^{1,3,4}$ (A) & 50 & & \\
\hline
\end{tabular}

SN Systemic necrosis

a Expected genotypic ratio for F2 population of 1 AA: 2 AG: 1 GG; $\chi^{2}=1.392, P=0.498(d f=2)$

${ }^{\mathrm{b}}$ Expected phenotypic ratio for $\mathrm{F} 2$ population of 1 resistant: 3 susceptible; $\chi^{2}=0.464, P=0.496(d f=1)$

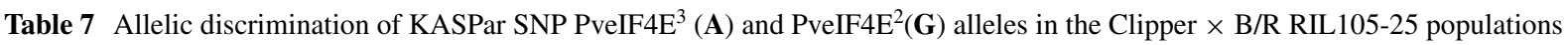

\begin{tabular}{|c|c|c|c|c|c|c|}
\hline Genotype & Population & $\begin{array}{l}\text { ClYVV } \\
\text { resistance }\end{array}$ & $\begin{array}{l}\text { PveIF4E }^{1,3,4} \_ \text {PveIF4E }^{2} \\
\text { SNP (A332G) }\end{array}$ & No. ${ }^{a}$ & Phenotype & No. \\
\hline Clipper & Parent 1 & cyvcyv & PveIF4E $^{1,3,4}$ (A) PveIF4E ${ }^{1,3,4}$ (A) & 18 & Resistant & 18 \\
\hline B/R RIL 105-25 & Parent 2 & $b c-3 b c-3$ & 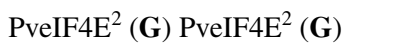 & 18 & Resistant & 18 \\
\hline Clipper $\times$ B/R RIL 105-25 & $\mathrm{F}_{1}$ & $\begin{array}{l}\text { cyvbc-3 } \\
\text { cyvcyv }\end{array}$ & $\begin{array}{l}\text { PveIF4E }^{1,3,4} \text { (A) PveIF4E }{ }^{2}(\mathbf{G}) \\
\left.\text { PveIF4E }^{1,3,4} \text { (A) PveIF4E } \text { Pr,3 }^{1,3,4}\right)\end{array}$ & $\begin{array}{l}18 \\
32\end{array}$ & Resistant & 18 \\
\hline Clipper $\times$ B/R RIL 105-25 & $\mathrm{F}_{2}$ & $\begin{array}{l}c y v b c-3 \\
b c-3 b c-3\end{array}$ & 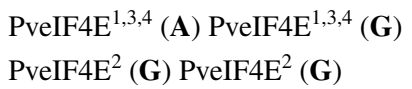 & $\begin{array}{l}65 \\
35\end{array}$ & Resistant & 132 \\
\hline
\end{tabular}

${ }^{a}$ Expected genotypic ratio for $\mathrm{F} 2$ population of $1 \mathrm{AA}: 2 \mathrm{AG}: 1 \mathrm{GG} ; \chi^{2}=0.166, P=0.921(d f=2)$

that the resistance from Jolanda is allelic with that possessed by Clipper and Amanda (previously reported as cyv by Tu 1983, and Park and Tu 1991, respectively). The assignment of the independent gene status and symbol desc was not warranted, nor does it appear to have ever been formally accepted by the BIC (Porch 2009). As the $b c-3$ gene symbol, first identified in IVT 7214 (Drijfhout 1978) was assigned prior to the designation of $c y v$, it retains priority as the gene symbol for the locus. The original $b c-3$ allele from IVT 7214 retains its designation as $b c-3$, and it conditions the widest spectrum of resistance to BCMV and BCMNV when in combination with $b c-u$ or $I$ (Kelly et al. 1995). The cyv allele first reported in GN 1140 should be designated $b c-3^{2}$ (Table 9) to reflect its recessive resistance to ClYVV-NY, its differential susceptibility to NL 3D, and the order in which it was discovered.

A causative relationship between mutations in PveIF4E and $b c-3$ resistance is probable based on the clear precedent of recessive potyvirus resistance conferred by amino acid substitutions in eIF4E. This can be the result of as few as one amino acid substitution, or in many cases, an allelic series of eIF4E is present where various subtle signature amino acid substitutions in the surface loops of the eIF4E protein confer unique strain and species-specific resistance spectra [the pvr2 alleles in Capsicum annuum (Charron et al. 2008; Kang et al. 2005b; Ruffel et al. 2002), the pot1 allele in Solanum lycopersicum (Ruffel et al. 2005), the mol allele in Lactuca sativa (Nicaise et al. 2003), the sbm 1 alleles in Pisum sativum (Andrade et al. 2009; BruunRasmussen et al. 2007; Gao et al. 2004), the rym4 and rym5 alleles in Hordeum vulgare (Hofinger et al. 2011; Stein et al. 2005), and the zym-FL allele in Citrullus lanatus (Ling et al. 2009)]. The pattern of predicted amino acid substitutions in the surface loops of PveIF4E and the complete association with differential resistance presented here closely resembles the numerous other pathosystems characterized. In addition, there is close alignment of mutations in PveIF4E with mutations in eIF4E that confer potyvirus resistance alleles present in the plant species $C$. аппиит (Kang et al. 2005b; Ruffel et al. 2002), L. sativa (Nicaise et al. 2003), and $P$. sativum (Bruun-Rasmussen et al. 2007; Gao et al. 2004) (Naderpour et al. 2010). Here we provide strong evidence for an association between a single amino acid substitution at position 76 (A76E) and resistance to ClYVV-NY, and for a single amino acid substitution at position 111 (D111G) and differential resistance to NL 3D.

This result parallels previous research that has revealed a co-evolutionary 'arms race' where positive Darwinian 
Table 8 PveIF4E haplotype analysis as enabled by the three KASPar assays employed in the research

\begin{tabular}{|c|c|c|c|c|c|}
\hline \multirow[t]{3}{*}{ Genotype } & \multirow{3}{*}{$\begin{array}{l}\mathrm{ClYVV}^{\mathrm{a}} \\
\text { resistance }\end{array}$} & \multirow[t]{3}{*}{ PveIF4E allele } & \multicolumn{3}{|l|}{ KASPar SNP assays } \\
\hline & & & PveIF4E $^{1} \_$PveIF4E ${ }^{2,3,4}$ & PveIF4E $^{1,4} \_$PveIF4E $E^{2,3}$ & PveIF4E $^{1,3,4}{ }_{\text {PveIF4E }}^{2}$ \\
\hline & & & SNP (C227A) & SNP (C159A) & SNP (A332G) \\
\hline Dubbele Witte & $\mathrm{S}$ & PveIF $4 E^{l}$ & PveIF4E $^{1}(\mathbf{C})$ & PveIF4E $^{1,4}(\mathbf{C})$ & PveIF4E ${ }^{1,3,4}(\mathbf{A})$ \\
\hline Midnight & $\mathrm{S}$ & PveIF4E ${ }^{l}$ & PveIF4E $^{1}(\mathbf{C})$ & PveIF4E $^{1,4}(\mathbf{C})$ & PveIF4E $1,3,4$ (A) \\
\hline Hystyle & S & PveIF4E & PveIF4E $^{1}(\mathbf{C})$ & PveIF4E $^{1,4}(\mathbf{C})$ & PveIF4E $E^{1,3,4}(\mathbf{A})$ \\
\hline GN 1140 & cyv & PveIF4E & PveIF4E ${ }^{2,3,4}(\mathbf{A})$ & PveIF4E $^{1,4}(\mathbf{C})$ & PveIF4E ${ }^{1,3,4}(\mathbf{A})$ \\
\hline Black Knight & cyv & PveIF4E & PveIF4E $2,3,4$ (A) & PveIF4E $^{1,4}(\mathbf{C})$ & PveIF4E $1,3,4$ (A) \\
\hline Jolanda & desc & PveIF4E 4 & PveIF4E $2,3,4$ (A) & PveIF4E $^{1,4}(\mathbf{C})$ & PveIF4E ${ }^{1,3,4}(\mathbf{A})$ \\
\hline Amanda & cyv & PveIF4E & PveIF4E ${ }^{2,3,4}$ (A) & PveIF4E $^{1,4}(\mathbf{C})$ & PveIF4E ${ }^{1,3,4}$ (A) \\
\hline Baby Bop & $r$ & PveIF4E & PveIF4E $2,3,4$ (A) & PveIF4E $^{1,4}(\mathbf{C})$ & PveIF4E ${ }^{1,3,4}(\mathbf{A})$ \\
\hline Laureat & $r$ & PveIF4E & PveIF4E $2,3,4$ (A) & PveIF4E $^{1,4}(\mathbf{C})$ & PveIF4E ${ }^{1,3,4}$ (A) \\
\hline Paloma & $r$ & PveIF4E & PveIF4E $2,3,4$ (A) & PveIF4E $^{1,4}(\mathbf{C})$ & PveIF4E ${ }^{1,3,4}(\mathbf{A})$ \\
\hline Polder & $r$ & PveIF4E & PveIF4E $2,3,4$ (A) & PveIF4E $^{1,4}(\mathbf{C})$ & PveIF4E $\mathrm{E}^{1,3,4}$ (A) \\
\hline Sonesta & $r$ & PveIF4E 4 & PveIF4E $2,3,4$ (A) & PveIF4E $^{1,4}(\mathbf{C})$ & PveIF4E $\mathrm{E}^{1,3,4}$ (A) \\
\hline Imuna & cyv, desc & PveIF4E & PveIF4E $2,3,4$ (A) & PveIF4E $^{2,3}$ (A) & PveIF4E ${ }^{1,3,4}$ (A) \\
\hline Evolutie & desc & PveIF4E & PveIF4E ${ }^{2,3,4}$ (A) & PveIF4E $^{2,3}$ (A) & PveIF4E ${ }^{1,3,4}$ (A) \\
\hline Clipper & cyv & PveIF $4 E^{3}$ & PveIF4E ${ }^{2,3,4}$ (A) & PveIF4E $E^{2,3}$ (A) & PveIF4E ${ }^{1,3,4}$ (A) \\
\hline $\mathrm{CY}-10 \mathrm{~S}_{4}$ & cyv & PveIF4E & PveIF4E $2,3,4$ (A) & PveIF4E ${ }^{2,3}$ (A) & PveIF4E ${ }^{1,3,4}$ (A) \\
\hline IVT 7214 & $b c-3$ & PveIF4E ${ }^{2}$ & PveIF4E $2,3,4$ (A) & PveIF4E $^{2,3}$ (A) & PveIF4E $^{2}(\mathbf{G})$ \\
\hline Raven & $b c-3$ & PveIF $4 E^{2}$ & PveIF4E $2,3,4$ (A) & PveIF4E $^{2,3}$ (A) & PveIF4E $^{2}(\mathbf{G})$ \\
\hline B/R RIL105-25 & $b c-3$ & PveIF4E & PveIF4E $2,3,4(\mathbf{A})$ & PveIF4E $^{2,3}$ (A) & PveIF4E $^{2}(\mathbf{G})$ \\
\hline USWK-6 & $b c-3$ & PveIF4E ${ }^{2}$ & PveIF4E $2,3,4$ (A) & PveIF4E $^{2,3}$ (A) & PveIF4E $^{2}(\mathbf{G})$ \\
\hline $\mathrm{USWKH} \times \mathrm{HS}_{4}$ & $b c-3$ & PveIF4E & PveIF4E ${ }^{2,3,4}(\mathbf{A})$ & PveIF4E $^{2,3}(\mathbf{A})$ & PveIF4E $^{2}(\mathbf{G})$ \\
\hline
\end{tabular}

a $S$ susceptible, $r$ resistant; confirmed by screening 5-10 plants of each cultivar in three independent experiments, with ' $r$ ' confirmed by ELISA

Table 9 Revised gene symbol nomenclature for the $B c-3$ locus

\begin{tabular}{lllll}
\hline Genotype & Accession \# & $\begin{array}{l}\text { ClYVV } \\
\text { resistance }\end{array}$ & $\begin{array}{l}\text { PveIF4E } \\
\text { allele }^{\mathrm{a}}\end{array}$ & $\begin{array}{l}\text { Gene } \\
\text { symbol }\end{array}$ \\
\hline Dubbele Witte & PI 549695 & Susceptible & PveIF4E $^{l}$ & Bc-3 \\
IVT 7214 & PI 602987 & $b c-3$ & PveIF4E $^{2}$ & $b c-3$ \\
Clipper & PI 278776 & cyv & PveIF4E $^{3}$ & $b c-3^{2 \mathrm{~b}}$ \\
GN 1140 & PI 549667 & cyv & PveIF4E $^{4}$ & \\
Jolanda & G 7591 & desc & &
\end{tabular}

${ }^{a}$ In the absence of direct functional complementation, PveIF4E remains as the candidate gene for $\mathrm{Bc}-3$

${ }^{\mathrm{b}}$ Proposed here and under review by the Bean Improvement Cooperative Genetics Committee

selection has acted on single amino acid sites of eIF4E to create recessive virus resistance genes as the result of coevolution with the virus, where the viral-encoded VPg functions as the pathogenicity determinant and is also under positive selection (Cavatorta et al. 2008; Charron et al. 2008; Moury et al. 2004). Statistical methods for inferring positive selection in combination with the a priori data available from eIF4E resistance alleles in $C$. аппиит (Charron et al. 2008), S. lycopersicum (Ruffel et al. 2005), and $P$. sativum (Gao et al. 2004) demonstrated high precision and power to positively identify the single amino acid sites involved in potyvirus resistance (Cavatorta et al. 2008). Remarkably, out of the ten amino acid positions examined, positions 76 and 110 were identified with the highest posterior probabilities (Cavatorta et al. 2008). In $C$. annuum, $P$. sativum, and $P$. vulgaris, resistance to a potyvirus is either confirmed, or associated with the substitution of an alanine amino acid residue at position 76 with either an aspartic residue (C. апnиит, $P$. sativum), proline residue ( $P$. sativum), or a glutamic acid residue (A76E) $(P$. vulgaris). The D111G amino acid substitution in PveIF4E ${ }^{2}$, and associated with differential resistance to NL $3 \mathrm{D}$, is also remarkably close to position 110 . Previous research has revealed that the pathogenicity determinant of the cyv resistance breaking strain (ClYVV-Br) maps to the central region of the VPg and is likely responsible for the restoration of pathogenicity (Sato et al. 2003).

Direct functional conferral of resistance and restoration of susceptibility is warranted, but common bean has lacked efficient transformation capabilities. A Bean pod mottle virus (BPMV) (family Comoviridae, genus Comovirus)based virus induced gene-silencing (VIGS) vector for 
common bean has recently been developed (Diaz-Camino et al. 2011) and may prove to be a useful tool for confirming the function of PveIF4E in potyvirus resistance in future research. Functional analysis of PveIF4E-potyvirus VPg interactions through protein-protein interaction experiments may also be warranted to better characterize, understand, and predict resistance spectra.

Establishment of the allelic relationships between the known sources of resistance to ClYVV in common bean directly informs the definition of the target genotype for the most effective resistance, at least in terms of the strains known in the United States. The possibility of pyramiding the previously identified putative independent genes is no longer possible, but it is clear that the original $b c-3$ allele from IVT7214 conditions the widest spectrum of resistance. The $b c-3$ allele is the only allele that conditioned resistance to all strains of ClYVV, including ClYVV-WI and ClYVV-OR, except when in the IVT 7214 background (Larsen et al. 2008), whereas $b c-3^{2}$ (present in Jolanda and Imuna) did not. It is difficult to speculate as to why IVT 7214 may be the exception, as it possesses the $b c-u$ allele that should condition the full expression of $b c-3$ (Drijfhout 1978). In addition, the genotype USCR- 8 that possesses $b c$ 3 in the absence of both the $I$ gene and $b c-u$ (Miklas and Hang 1998) was resistant to ClYVV-WI and ClYVV-OR (Larsen et al. 2008). It is still somewhat unclear whether $b c-3$ or $b c-3^{2}$ are effective for resistance to ClYVV in the absence of $b c$-u and/or $I$ because all of the genotypes investigated in this research possessed one, or both genes. Another exception is GN 1140, as while it possesses $b c$ $3^{2}$, and is mildly susceptible to NL 3D, it was resistant to ClYVV-WI and CIYVV-OR (Larsen et al. 2008). The genotype GN UI 31 may be an analogous case as it was the source of two recessive genes that conditioned resistance to the BYMV-S strain from Oregon (Tatchell et al. 1985), so it is feasible that GN 1140 and GN UI 31 possess an additional resistance gene, perhaps an alternate allele of $b c$ $u$ (Strausbaugh et al. 2003) that widen their strain-specific resistance spectrum to include CIYVV-WI and CIYVV-OR where other $b c-3^{2}$ genotypes do not (Larsen et al. 2005). GN UI 31 has been demonstrated to have mixed reactions to specific BCMV/BCMNV strains potentially due to admixture or residual heterozygosity in previous research (Forster et al. 1994; Miklas et al. 2000). Additional effort is needed to obtain a more thorough characterization of the spectrum of resistance to ClYVV and BCMV/BCMNV pathogenicity groups provided by $b c-3^{2}$ alone, and in combination with $b c-u$ and/or $I$.

The three KASPar assays developed here provide a suite of rapid, user-friendly, putatively functional molecular markers that have the capability to detect and differentiate all four of the PveIF4E alleles characterized thus far. These assays are an improvement over the RsaI CAPS marker associated with $b c-3$ resistance (Naderpour et al. 2010) because in addition to the PveIF4E $E^{2}$ allele, the RsaI site at position 193 of the coding sequence is also present in the PveIF4E ${ }^{3}$ allele (Online Resource 1, Fig. 1, Fig. 3), which is not associated with resistance to NL 3D. The PveIF4E KASPar assays are also more convenient to employ in marker-assisted selection (MAS) because they do not require enzymatic digestion or gel electrophoresis; however, they do require fluorescent endpoint detection capabilities. The RsaI CAPS marker, therefore, remains useful when this capability is absent, but the resistance to NL 3D of the donor parent must be known or confirmed. The discrimination capability of the KASPar assays developed here may also have the potential for rapid characterization of germplasm through the detection of mutant alleles, particularly for detecting predicted amino acid substitutions at positions 76 and 111. Table 8 summarizes the employment of the three assays for allelic discrimination in the 21 common bean genotypes studied and simultaneously provides a guide on how to use the KASPar assays for allelic discrimination and MAS.

This research contributes to an enhanced understanding of the gene-for-gene relationships between potyviruses and resistance alleles associated with mutations in PveIF4E at the $B c-3$ locus in common bean. This knowledge combined with the KASPar assays continues in the development of a platform to elucidate the role of eIF4E-mediated recessive resistance in common bean. Advanced research in this area in other crop plants has been rewarding, with new insights into the biology [e.g. complementation interactions with mutations in eIF(iso)4E for an enhanced resistance spectrum (Hwang et al. 2009; Rubio et al. 2009; Ruffel et al. 2006)], the demonstration of new tools for rapid identification of novel alleles by allele mining [e.g. High-resolution melting analysis (HRM) (Hofinger et al. 2009; Hofinger et al. 2011)], and to even create novel resistance alleles by mutagenesis (Piron et al. 2010). The research presented here provides a foundation on which to advance similar research in common bean. The KASPar assays developed here should also assist in the utilization of $b c-3$ resistance, important to common bean growing regions around the world.

Acknowledgments The authors wish to thank James Kelly, Phil Miklas, Elise Vendeuvre, and Molly Welsh for provision of bean germplasm. A special thanks is due to Jason Cavatorta for his initial assistance with preliminary research and Michael Mazourek for providing laboratory space. We acknowledge the technical assistance of Matt Wavrick, and Sarah Durkee. We also thank two anonymous reviewers whose suggestions helped to improve the manuscript. This research was supported through funding from the New York State Vegetable Research Association. John Hart was provided with support from Pioneer Hi-Bred Intl. through Cornell University's Department of Plant Breeding and Genetics, a Cornell Graduate School Fellowship, and the Bullis Fellowship of the NYSAES. 


\section{References}

Afanador LK, Haley SD, Kelly JD (1993) Adoption of a mini-prep DNA extraction method for RAPD marker analysis in common bean (Phaseolus vulgaris L.). Annu Rep Bean Improv Coop 35:10-11

Ali MA (1950) Genetics of resistance to the common bean mosaic virus in the bean (Phaseolus vulgaris L.). Phytopathol 40:69-79

Andrade M, Abe Y, Nakahara KS, Uyeda I (2009) The cyv-2 resistance to Clover yellow vein virus in pea is controlled by the eukaryotic initiation factor 4E. J Gen Plant Pathol 75:241-249

Boodley JW, Sheldrake R (1972) Cornell peat-lite mixes for commercial plant growing. Cornell Info Bull 43:1-8

Bos L, Lindsten K, Maat DZ (1977) Similarity of Clover yellow vein virus and Pea necrosis virus. Neth J Plant Pathol 83:97-108

Bruun-Rasmussen M, Moller IS, Tulinius G et al (2007) The same allele of translation initiation factor $4 \mathrm{E}$ mediates resistance against two Potyvrius spp. in Pisum sativum. Molec Plant Microb Interact 9:1075-1082

CABI/EPPO (2000) Clover yellow vein potyvirus. Distribution maps of plant diseases. CAB International, Wallingford, $\mathrm{p} 811$

Cavatorta JR, Savage AE, Yeam I, Gray SM, Jahn MM (2008) Positive darwinian selection at single amino-acid sites conferring plant virus resistance. J Mol Evol 67:551-559

Charron C, Nicolai M, Gallois JL et al (2008) Natural variation and functional analyses provide evidence for co-evolution between plant eIF4E and potyviral VPg. Plant J 54:56-68

Collmer CW, Marston MF, Taylor JC, Jahn M (2000) The I gene of bean: a dosage- dependent allele conferring extreme resistance, hypersensitive resistance, or spreading vascular necrosis in response to the Potyvirus Bean common mosaic virus. Molec Plant-Microbe Interact 13:1266-1270

Crnov R, Gilbertson RL (2001) Outbreak of Clover yellow vein virus in a bean field in Colusa County, California. Plant Dis 85:444

Diaz-Camino C, Annamalai P, Sanchez F et al (2011) An effective virus-based gene silencing method for functional genomics studies in common bean. Plant Methods 7:16

Diaz-Pendon JA, Truniger V, Nieto C et al (2004) Advances in understanding recessive resistance to plant viruses. Molec Plant Pathol $5: 223-233$

Dizadji A, Shahraeen N (2011) Occurrence, distribution and seasonal changes of viruses infecting common bean in northwestern Iran. Arch Phytopathol Plant Prot 44(17):1647-1654

Drijfhout E (1978) Genetic interaction between Phaseolus vulgaris and Bean common mosaic virus with implications for strain identification and breeding for resistance. Agric Res Rep 872:1-98

Drijfhout E, Silbernagel MJ, Burke DW (1978) Differentiation of strains of Bean common mosaic virus. Neth J Plant Pathol $84: 13-26$

Forster RL, Strausbaugh CA, Stewart-Williams K, Myers JR (1994) Determination of resistance to BCMV in dry edible bean cultivars and breeding lines. Annu Rep Bean Improv Coop 37:1-8

Gao A, Johansen E, Eyers S et al (2004) The potyvirus recessive resistance gene, $s b m 1$, identifies a novel role for translation initiation factor eIF4E in cell-to-cell trafficking. Plant J 40:376-385

Halseth DE, Myers JR, Stewart-Williams K, Scully B (1998) Registration of 'Black Knight' black bean. Crop Sci 38:883

Hill JH, Alleman R, Hogg DB, Grau CR (2001) First report of transmission of Soybean mosaic virus and Alfalfa mosaic virus by Aphis glycines in the New World. Plant Dis 85:561

Hjulsager CK, Lund OS, Johansen IE (2002) A new pathotype of pea seed-borne mosaic virus explained by properties of the P3-6K1 and viral genome-linked (VPg) coding regions. Mol Plant Microb Interact 15:169-171
Hofinger BJ, Jing HC, Hammond-Kossack KE, Kanyuka K (2009) High-resolution melting analysis of cDNA-derived PCR amplicons for rapid and cost-effective identifications of novel alleles in barley. Theor Appl Genet 119:851-865

Hofinger BJ, Russell JR, Bass CG et al (2011) An exceptionally high nucleotide and haplotype diversity and a signature of positive selection for the $e I F 4 E$ resistance gene in barley are revealed by allele mining and phylogenetic analyses of natural populations. Molec Ecol 20:3653-3668

Hwang J, Li J, Liu W et al (2009) Double mutations in eIF4E and eIFiso4E confer recessive resistance to Chilli veinal mottle virus in Pepper. Mol Cells 27:329-336

Johnson WC, Guzman P, Mandala D, Mkandawire ABC, Temple S, Gilbertson RL, Gepts P (1997) Molecular tagging of the $b c$ 3 gene for introgression into Andean common bean. Crop Sci 37:248-254

Kang BC, Yeam I, Jahn MM (2005a) Genetics of plant virus resistance. Annu Rev Phytopathol 43:581-621

Kang BC, Yeam I, Frantz JD et al (2005b) The pvrl locus in Capsicum encodes a translation initiation factor eIF4E that interacts with Tobacco etch virus VPg. Plant J 42:392-405

Keller KE, Johansen IE, Martin RR, Hampton RO (1998) Potyvirus genome-linked protein VPg determines pea-seed borne mosaic virus pathotype-specific virulence in Pisum sativum. Molec Plant Microb Interact 11:124-130

Kelly JD, Hosfield GL, Varner GV, Uebersax MA, Haley SD, Taylor J (1994) Registration of 'Raven' black bean. Crop Sci 34: $1406-1407$

Kelly JD, Afanador L, Haley SD (1995) Pyramiding genes for resistance to bean common mosaic virus. Euphytica 82:207-212

Kelly JD, Gepts P, Miklas PN, Coyne DP (2003) Tagging and mapping of genes and QTL and molecular-marker assisted selection for traits of economic importance in bean and cowpea. Field Crops Res 82:135-154

Larsen RC, Myers JR (2006) A pod necrosis disease ('chocolate pod') of snap bean (Phaseolus vulgaris) in Oregon caused by a strain of Clover yellow vein virus. Phytopathol 96:S169

Larsen RC, Miklas PN, Eastwell CR et al (2002) A virus disease complex devastating late season snap bean production in the Midwest. Annu Rep Bean Improv Coop 45:36-37

Larsen RC, Miklas PN, Druffel KL, Wyatt SD (2005) NL-3 K strain is a stable and naturally occurring interspecific recombinant derived from Bean common mosaic necrosis virus and Bean common mosaic virus. Phytopathol 95:1037-1042

Larsen RC, Miklas PN, Eastwell KC, Grau CR (2008) A strain of Clover yellow vein virus that causes severe pod necrosis disease in snap bean. Plant Dis 92:1026-1032

LeGall O, Aranda MA, Caranta C (2011) Plant resistance to viruses mediated by translation initiation factors. In: Caranta $\mathrm{C}$ et al (eds) Recent advances in plant virology. Caister Academic Press, Norfolk, pp 177-194

Lellis AD, Kasschau KD, Whitham SA, Carrington JC (2002) Lossof-susceptibility mutants of Arabidopsis thaliana reveal an essential role for eIF(iso)4E during potyvirus infection. Curr Biol 12:1046-1051

Ling KS, Harris R, Meyer JDF (2009) Non-synonymous single nucleotide polymorphisms in the watermelon eIF4E gene are closely associated with resistance to Zucchini yellow mosaic virus. Theor Appl Genet 120:191-200

McKern NM, Mink GI, Barnett OW, Mishra A, Whittaker LA, Silbernagel MJ, Ward CW, Shukla DD (1992) Isolates of bean common mosaic virus comprising two distinct potyviruses. Phytopathol 82:923-928

Miklas PN, Hang AN (1998) Release of cranberry dry bean germplasm lines USCR-7 and USCR-8 with resistance to bean 
common mosaic and necrosis viruses. Annu Rep Bean Improv Coop 41:227-228

Miklas PN, Lambert S, Mink G, Silbernagel M (1998) Many beans with $b c-3$ resistance to BCMNV are susceptible to BCMV. Annu Rep Bean Improv Coop 41:33-34

Miklas PN, Larsen RC, Riley R, Kelly J (2000) Potential markerassisted selection for $b c-1^{2}$ resistance to bean common mosaic potyvirus in common bean. Euphtyica 116:211-219

Miklas PN, Hang AN, Kelly JD, Strausbaugh CA, Forster RL (2002) Registration of three kidney bean germplasm lines resistant to bean common mosaic and necrosis potyviruses: USLK-2 light red kidney, USDK-4 dark red kidney, and USWK-6 white kidney. Crop Sci 42:674-675

Morales FJ (2005) Bean common mosaic. In: Shwartz HF (ed) Compendium of Bean diseases. American Phytopathol Soc, St. Paul MN, pp 60-63

Moury B, Morel C, Johansen E et al (2004) Mutations in potato virus $\mathrm{Y}$ genome-linked protein determine virulence toward recessive resistances in Capsicum annuиm and Lycopersicon hirsutum. Mol Plant Microbe Interact 17:322-329

Mukeshimana G, Paneda A, Rodriguez-Suarez C et al (2005) Markers linked to the $b c-3$ gene conditioning resistance to bean common mosaic potyviruses in common bean. Euphtyica 144: 291-299

Naderpour M, Søgaard Lund O, Larsen R, Johansen E (2010) Potyviral resistance derived from cultivars of Phaseolus vulgaris carrying $b c-3$ is associated with the homozygotic presence of a mutated $e I F 4 E$ allele. Mol Plant Pathol 11:255-263

Nault LR (1997) Arthropod transmission of plant viruses: a new synthesis. Ann Entomol Soc Am 90:521-541

Nault BA, Shah DA, Dillard HR, McFaul AC (2004) Seasonal and spatial dynamics of alate aphid dispersal in snap bean fields in proximity to alfalfa and implications for virus management. 33:1593-1601

Nicaise V, German-Retana S, Sanjuán R et al (2003) The eukaryotic translation initiation factor $4 \mathrm{E}$ controls lettuce susceptibility to the potyvirus Lettuce mosaic virus. Plant Physiol 132:1272-1282

Nicolas O, Dunnington SW, Gotow LF et al (1997) Variations in the VPg protein allow a potyvirus to overcome va gene resistance in tobacco. Virol 237:452-459

Ortiz V, Castro S, Romero J (2009) First report of Clover yellow vein virus in grain legumes in Spain. Plant Dis 93:106

Park SJ, Tu JC (1991) Inheritance and allelism of resistance to a severe strain of bean yellow mosaic virus in common bean. Can $\mathrm{J}$ Plant Pathol 13:7-10

Pedrosa-Harand A, Porch T, Gepts P (2008) Standard nomenclature for common bean chromosomes and linkage groups. Annu Rept Bean Improv Coop 51:106-107

Phaseolus vulgaris V1.0, DOE-JGI and USDA-NIFA (2013) http://www.phytozome.net/commonbean. Accessed 08 May 2013

Piron F, Nicolai M, Minoia S et al (2010) An induced mutation in tomato $e I F 4 E$ leads to immunity to two potyviruses. PLoS One 5:e11313

Porch T (2009) List of genes-Phaseolus vulgaris L. Bean Improvement Cooperative. http://www.css.msu.edu/bic/PDF/Bean_Genes_ List_2010.pdf. Accessed 23 Oct 2012

Porch T (2012) Phaseolus Genes and Gene Symbol Nomenclature, Bean Improvement Cooperative Genetics Committee. www.css.msu.edu/bic/_pdf/Gene_Committee_Rules.pdf. Accessed 23 Oct 2012

Provvidenti R (1987) List of genes in Phaseolus vulgaris for resistance to viruses. Annu Rep Bean Improv Coop 30:1-4

Provvidenti R, Morales FJ (2005) Clover yellow vein. In: Shwartz HF (ed) Compendium of Bean Diseases. American Phytopathol Soc, St. Paul, pp 75-76
Provvidenti R, Schroeder WT (1973) Resistance in Phaseolus vulgaris to the severe strain of Bean yellow mosaic virus. Phytopathol 63:196-197

Ragsdale DW, Voegtlin DJ, O'Neil RJ (2004) Soybean aphid biology in North America. Ann Entomol Soc Am 97:204-208

Robaglia C, Caranta C (2006) Translation initiation factors: a weak link in plant RNA virus infection. Trends Plant Sci 11:40-45

Robinson P, Holmes J (2011) KASP version 4.0 SNP Genotyping Manual. Kbioscience. http://www.lgcgenomics.com/bbpPage/ download/slug/kasp-technicalresources/link/337ad5493211ff491 791f7d95469b0285eae1c1c.pdf. Accessed 23 Oct 2012

Rozen S, Skaletsky HJ (2000) Primer3 on the www for general users and for biologist programmers. In: Krawetz S, Misener S (eds) Bioinformatics methods and protocols: methods in molecular biology. Humana Press, Totowa, pp 365-386

Rubio M, Nicolai M, Caranta C, Palloix A (2009) Allele mining in the pepper gene pool provided new complementation effects between pvr2-eIF4E and pvr6-eIF(iso) $4 E$ alleles for resistance to pepper veinal mottle virus. J Gen Virol 90:2808-2814

Ruffel S, Dussault MH, Palloix A et al (2002) A natural recessive resistance gene against potato virus $\mathrm{Y}$ in pepper corresponds to the eukaryotic initiation factor 4E (eIF4E). Plant J 32: 1067-1075

Ruffel S, Dussault MH, Palloix A et al (2005) The recessive potyvirus resistance gene pot-1 is the tomato orthologue of the pepper pvr2-eIF4E gene. Mol Gen Genomics 274:346-353

Ruffel S, Gallois J, Moury B et al (2006) Simultaneous mutations in translation initiation factors eIF4E and eIF(iso)4E are required to prevent pepper veinal mottle virus infection of pepper. J Gen Virol 87:2089-2098

Sasaya T, Shimizu T, Nozu Y et al (1997) Biological, serological, and molecular variabilities of Clover yellow vein virus. Phtyopathol 87:1014-1019

Sato M, Masuta C, Uyeda I (2003) Natural resistance to Clover yellow vein virus in beans controlled by a single recessive locus. Molec Plant Microb Interact 16:994-1002

Schmutz J, Cannon SB, Schlueter J et al (2010) Genome sequence of the palaeopolyploid soybean. Nature 463:178-183

Shah DA, Dillard HR, Mazumdar-Leighton S (2006) Incidence, spatial patterns, and associations among viruses in snap bean and alfalfa in New York. Plant Dis 90:203-210

Shail J, Taylor AG, Provvidenti R (2007) Bioassays to diagnose selected bean potyviruses. Annu Rep Bean Improv Coop 50:81-82

Slater GSC, Birney E (2005) Automated generation of heuristics for biological sequence comparison. BMC Bioinforma 6:31

Stein N, Perovic D, Kumlehn J et al (2005) The eukaryotic translation initiation factor $4 \mathrm{E}$ confers multiallelic recessive Bymovirus resistance in Hordeum vulgare (L.). Plant J 42:912-922

Strausbaugh CA, Miklas PN, Singh SP, Myers JR, Forster RL (2003) Genetic characterization of differential reactions among host group 3 common bean cultivars to NL-3 K strain of Bean common mosaic virus. Phytopathol 93:683-690

Tatchell SP, Baggett JR, Hampton RO (1985) Relationship between resistance to severe and type strains of Bean yellow mosaic virus. J Am Soc Hort Sci 110:96-99

Tracy SL, Frenkel MJ, Gough KH et al (1992) Bean yellow mosaic, clover yellow vein, and pea mosaic are distinct potyviruses: evidence from coat protein gene sequences and molecular hybridization involving the $3^{\prime}$ non-coding regions. Arch Virol 122:249-261

Truniger V, Aranda MA (2009) Recessive resistance to plant viruses. Adv Virus Res 75:119-159

Tu JC (1980) Occurrence and identification of a flexuous rod virus from a mosaic complex of white beans in southern Ontario. Phytopathol Z 99:163-174 
Tu JC (1983) Inheritance in Phaseolus vulgaris cv. Kentwood of resistance to a necrotic strain of bean yellow mosaic virus and to a severe bean strain of tobacco ringspot virus. Can J Plant Pathol 5:34-35

Tu JC (1988) Bean yellow mosaic: now the most severe virus disease of white beans in southwestern Ontario. Annu Rep Bean Improv Coop 31:143

United States Department of Agriculture National Agricultural Statistics Service (USDA- NASS) (2011) Washington, DC. http://quickstats.nass.usda.gov/. Accessed 23 Oct 2012
Uyeda I, Takahasi T, Shikata E (1991) Relatedness of the nucleotide sequence of the $3^{\prime}$ - terminal region of clover yellow vein potyvirus RNA to bean yellow mosaic potyvirus RNA. Intervirol 32:234-245

Wang A, Krishnaswamy S (2012) Eukaryotic translation initiation factor 4E-mediated recessive resistance to plant viruses and its utility in crop improvement. Mol Plant Pathol 7:795-803 